\title{
The January Effect across Volatility Regimes*
}

\author{
Betty Agnani and Henry Aray ${ }^{\dagger}$ \\ University of Granada
}

March 2008

\begin{abstract}
Using a Markov regime switching model, this article presents evidence on the well-known January effect on stock returns. The specification allows a distinction to be drawn between two regimes, one with high volatility and other with low volatility. We obtain a time-varying January effect that is, in general, positive and significant in both volatility regimes. However, this effect is larger in the high volatility regime. In sharp contrast with most previous literature we find two major results: i) the January effect exists for all size portfolios. ii) the negative correlation between the magnitude of the January effect and the size of portfolios fails across volatility regimes. Moreover, our evidence supports a decline in the January effect for all size portfolios except the smallest, for which it is even larger.
\end{abstract}

Keywords: Markov Switching Model, Stock Returns, Seasonality, Size Portfolios.

JEL Classification: C22,G14

${ }^{*}$ We would like to thank participants of the XVI International Tor Vergata Conference on Banking and Finance for comments. Financial support from the Spanish Ministry of Education and Science, through Project SEJ2007-62081/ECON is gratefully acknowledged.

†Corresponding author: Universidad de Granada, Campus de la Cartuja S/N, Facultad de Ciencias Económicas y Empresariales, Departamento de Teoría e Historia Económica, 18011, Granada, Spain. E-mails: bagnani@ugr.es (B. Agnani), haray@ugr.es (H. Aray). Tel.: +34 958 243726; Fax: +34 958249995. 


\section{Introduction}

It is widely known in empirical finance that stock returns can undergo seasonality patterns. At daily frequency, the best known are the day-ofthe-week and macroeconomic-announcement effects. At monthly level, the January effect has become the most widely studied. Since the seminal work of Rozeff and Kinney (1976) many articles have tested the statistical significance of this effect or have tried to explain why stock returns are abnormally larger in January. The early articles of Keim (1983), Reinganum (1983) and Roll (1983), using US data, found that the January effect exists primarily for small stocks.

Among the explanations of the January, the most popular one is the tax-loss selling hypothesis. Chen and Singal (2004) present a comprehensive study of several explanations and find evidence in favor of the tax-loss selling hypothesis and little or no evidence for the other hypothesis. By contrast, Kim (2006) constructs a common risk factor related to information uncertainty caused by earnings volatility and claims to have found an improvement in explaining the abnormal returns in January; and Choudhry (2001), using pre-World war data, shows that non-tax factors may be responsible for the January effect. Although most evidence supports the tax-loss selling hypothesis the discussion remains open.

The January effect seems to be a worldwide phenomenon. Although most of the evidence gathered is for the US stock market, there are many articles analyzing the effect elsewhere. Bergs et al. (1984) find evidence for Canada, Hillier and Marshall (2002) for the UK, Choudhry (2001) for the US and UK but not for Germany. Silvapulle (2004) uses data on OECD countries and emerging economies. Asteriou and Kavetsos (2006), Galariotis (2004) and Tonchev and Kim (2004) use data on European emerging markets. Zhang and $\mathrm{Li} \mathrm{(2006)}$ use data on the Chinese stock market and Lean et al. (2007) provide evidence on several Asian stock markets.

The January effect is not an exclusive anomaly of stock returns, as shown by Al-Khazali (2001) and Starks et al. (2006), who find evidence for bond markets and by Rendon and Ziemba (2007) who find evidence for futures markets.

The January effect has also become important since that it can be used as a predictor of the returns over the following 11 months, which is called the "other January effect" by Cooper et al. (2006). They show that January returns have predictive power for market returns over the next 11 months of 
the year even after controlling for macroeconomic business cycles variables, the Presidential Cycle and investor sentiment. They also find that the "other January effect" persists among both large and small capitalization stocks and among both value and growth stocks.

This article revises the statistical significance of the January effect using a Markov switching model a la Hamilton (1989), which allows us to account for different volatility regimes. We propose a time-varying January effect for size portfolios. Chien et al. (2002) warn of the use of the dummy variable approach with constant variance since the estimators could be upward biased. Therefore, the Markov switching approach allows such drawbacks to be overcome.

Little analysis has been conducted considering different volatility regimes of stock returns and the January effect. Chia-Shang et al. (2004) used a Markov switching approach and found no evidence of the January effect for the return of the market portfolio. However, they do find evidence for returns on low capitalization stock portfolios. They fail in that they do not account for the dummy variable for January months, as commonly used in literature, and do not carry out formal inferences. Our model is much richer since that estimations for size portfolios are controlled for the three factors of Fama and French $(1993,1996)$. In fact, our specification allow us to determine that one part of the January effect on size portfolios accrues through those factors.

Consistently with previous literature, our results show that the January effect is in general positive. Furthermore, it is exists for all size portfolios by contrast with most previous evidence that relates the January effect with small size portfolios. We have also found that the negative correlation between the magnitude of the January effect and the size of portfolios is not fulfilled across volatility regimes. Therefore, our proposal could be interesting for practitioners since that those are major results to be taken into account for portfolio decision making.

Yanxiang $\mathrm{Gu}$ (2003) and Marquering et al. (2006) show that there is a decline in the January effect. Our time-varying approach supports a decline in the January effect, albeit one that is not so noticeable as they claimed.

The rest of the article is organized as follows. Section 2 presents the formal econometric model, Section 3 shows the data and the main results, and we give some conclusions in Section 4 . 


\section{The Econometric Model}

Denote high (low) volatility regimes by $h(l)$ and consider the simple two regime Markov switching model à la Hamilton (1989),

$$
r_{i t}=\rho_{i t}^{h} \mu_{i t}^{h}+\left(1-\rho_{i t}^{h}\right) \mu_{i t}^{l}+\varepsilon_{i t}
$$

Where $r_{i t}$ is the return on $i$ stock in the $t$ period, $\mu_{i t}^{h}\left(\mu_{i t}^{l}\right)$ is the conditional mean in the regimen $h(l), \rho_{i t}^{h}\left(1-\rho_{i t}^{h}\right)$ is the conditional probability of being in regimen $h(l)$ and $\varepsilon_{i t}$ is a iid disturbance. The conditional means can be written as follows

$$
\begin{aligned}
\mu_{i t}^{h} & =\alpha_{i}^{h}+\gamma_{i}^{h} D_{t}+F_{t}^{\prime} \beta_{i}^{h} \\
\mu_{i t}^{l} & =\alpha_{i}^{l}+\gamma_{i}^{l} D_{t}+F_{t}^{\prime} \beta_{i}^{l}
\end{aligned}
$$

Where $D_{t}$ is a dummy variable that takes the value of one in January and zero otherwise, $F_{t}$ is a vector containing the three factors of Fama and French (1993, 1996), referred to below as FFF.

It can be argued that the variable $D_{t}$ also affects the $F F F$, therefore a model accounting for the January effect on $F_{t}$ in a Markov switching setting can be written as

$$
F_{t}=P_{t}^{h}\left(\Pi^{h} D_{t}\right)+\left(I-P_{t}^{h}\right)\left(\Pi^{l} D_{t}\right)+U_{t}
$$

Where $P_{t}^{h}\left(I-P_{t}^{h}\right)$ is a $(3 \times 3)$ diagonal matrix that contains the conditional probabilities of the $F F F$ of being in regimen $h(l), I$ is a $(3 \times 3)$ identity matrix, $\Pi^{h}$ and $\Pi^{l}$ are $(3 \times 1)$ vectors of parameters and $U_{t}$ is a $(3 \times 1)$ vector of orthogonal iid disturbances.

Substituting firstly (3) in (2) and then (2) in (1) we get

$$
\begin{aligned}
r_{i t}= & \rho_{i t}^{h}\left[\alpha_{i}^{h}+\gamma_{i}^{h} D_{t}+\left(\left(P_{t}^{h} \Pi^{h}\right)^{\prime} D_{t}+\left[\left(I-P_{t}^{h}\right) \Pi^{l}\right]^{\prime} D_{t}+U_{t}^{\prime}\right) \beta_{i}^{h}\right]+ \\
& \left(1-\rho_{i t}^{h}\right)\left[\alpha_{i}^{l}+\gamma_{i}^{l} D_{t}+\left(\left(P_{t}^{h} \Pi^{h}\right)^{\prime} D_{t}+\left[\left(I-P_{t}^{h}\right) \Pi^{l}\right]^{\prime} D_{t}+U_{t}^{\prime}\right) \beta_{i}^{l}\right]+\varepsilon_{i t}
\end{aligned}
$$

An estimation of the equation (4) can be obtained by defining the auxiliary vector $D_{t}^{*}=P_{t}^{h} \mathbf{1} D_{t}$, where $\mathbf{1}$ is a $(3 \times 1)$ vector of ones, so that a new equation is written as 


$$
\begin{aligned}
r_{i t}= & \rho_{i t}^{h}\left[\alpha_{i}^{h}+\theta_{i}^{h} D_{t}+\left(D_{t}^{*}\right)^{\prime} \phi_{i}^{h}+U_{t}^{\prime} \beta_{i}^{h}\right]+ \\
& \left(1-\rho_{i t}^{h}\right)\left[\alpha_{i}^{l}+\theta_{i}^{l} D_{t}+\left(D_{t}^{*}\right)^{\prime} \phi_{i}^{l}+U_{t}^{\prime} \beta_{i}^{l}\right]+\varepsilon_{i t}
\end{aligned}
$$

with

$$
\begin{aligned}
\theta_{i}^{h} & =\gamma_{i}^{h}+\left(\Pi^{l}\right)^{\prime} \beta_{i}^{h} \\
\theta_{i}^{l} & =\gamma_{i}^{l}+\left(\Pi^{l}\right)^{\prime} \beta_{i}^{l} \\
\phi_{i}^{h} & =\left(\Pi^{h}-\Pi^{l}\right) \odot \beta_{i}^{h} \\
\phi_{i}^{l} & =\left(\Pi^{h}-\Pi^{l}\right) \odot \beta_{i}^{l}
\end{aligned}
$$

where $\odot$ represents element-by-element Hadamard multiplication.

Notice that $\theta_{i}^{h}$ and $\theta_{i}^{l}$ are the sum of a direct effect and a joint indirect effect of the $F F F$ and $\phi_{i}^{h}$ and $\phi_{i}^{l}$ are $(3 \times 1)$ vectors that collect the individual indirect effects of the $F F F$.

We calculate the time-varying January effect in each regime taking into account only the significant coefficients at $5 \%$ level in $\theta_{i}^{h}, \theta_{i}^{l}, \phi_{i}^{h}$ and $\phi_{i}^{l}$ as $^{1}$

$$
\begin{aligned}
\delta_{i t}^{h} & =\rho_{i t}^{h}\left[\theta_{i}^{h}+\left(\mathbf{1}^{\prime} P_{t}^{h}\right) \phi_{i}^{h}\right] \\
\delta_{i t}^{l} & =\left(1-\rho_{i t}^{h}\right)\left[\theta_{i}^{l}+\left(\mathbf{1}^{\prime} P_{t}^{h}\right) \phi_{i}^{l}\right]
\end{aligned}
$$

Finally, we can calculate the total time-varying January effect simply as

$$
\lambda_{i t}=\delta_{i t}^{h}+\delta_{i t}^{l}
$$

The log-likelihood function with normal disturbances to be maximized is,

$$
\log L\left(r_{i T}, \Theta\right)=\sum_{t=1}^{T} \log \left[\rho_{i t}^{h} f_{i t}^{h}+\left(1-\rho_{i t}^{h}\right) f_{i t}^{l}\right]
$$

where

$$
f_{i t}^{j}=\frac{1}{\sqrt{2 \pi v_{i t}^{j}}} \exp \left(-\frac{\left(\varepsilon_{i t}^{j}\right)^{2}}{2 v_{i t}^{j}}\right) \quad \text { for } j=h, l
$$

\footnotetext{
${ }^{1}$ Otherwise their values are supposed zero.
} 
$\Theta$ is a vector that brings together the parameters to be estimated and $v_{i t}^{j}$ is the conditional variance in state $j$ which is assumed to follow an $\mathrm{ARCH}(1)$.

The model is estimated in stages. First, we estimate equation (3) by equation and obtain the matrix $P_{t}^{h}$ and the vectors $\Pi^{h}, \Pi^{l}$ and $U_{t}$. Next, we construct the vector $D_{t}^{*}$ and estimate the parameters of equation (5) and the probabilities in each regime, $\rho_{i t}^{h}$ and $\left(1-\rho_{i t}^{h}\right)$, for each stock. ${ }^{2}$ Finally, we obtain the time-varying January effect as in (6) and (7).

\section{$3 \quad$ Data and Empirical Issues}

We use a sample of monthly returns on five size portfolios from US data from January 1940 to December 2006. Call the smallest one $q_{1}$ and the largest one $q_{5}{ }^{3}$ The data are from the Ken French's website. We use excess return on the one month T-bill.

First, let us present evidence on the January effect on the FFF ( $E R M$, $S M B, H M L)$. We estimate equation (3), with the results presented in Table 1. The most striking point in Table 1 is that the January effect is positive and only significant at the $5 \%$ level in the low volatility regime for $E R M$ and $S M B$. However, for $H M L$ it is significant at the $5 \%$ level in both regimes. We calculate the conditional mean for the FFF as in (3) taking into account only the coefficients estimated as significant at the $5 \%$ level and we obtain that the January effect is much larger for factor $H M L$. On average, over the sample period, the abnormal return in January is $0.72 \%$ for $E R M, 0.86 \%$ for $S M B$ and $2.33 \%$ for $H M L$. The larger value for $H M L$ could be explained by the fact that market participants may recompose their portfolios mainly in favor of undervalued stocks in January.

Table 2 shows the estimation of the parameters of equation (5). In general, we can say that, according to all the significant coefficients at the $5 \%$ level, the January effect affects all size portfolios, which contrasts with most previous evidence that found significant January effect primarily for small size portfolios. Moreover, the January effect for size portfolios is significant in both volatility regimes. Although, the number of significant coefficients is larger in low volatility regime, according to the Table 2, the January effect

\footnotetext{
${ }^{2}$ It is well-known that the likelihood function in (8) can have no overall maximum. We use 30 different starting points to confirm the overall maximum.

${ }^{3}$ Portfolios are formed in quintiles. $q_{1}$ contains the stocks in the first quintile and $q_{5}$ contains the stocks in the fifth quintile.
} 
is substantially larger in the high volatility regime. This result could have the following simple and logical explanation: when the volatility of stock markets is high there may be so much information and high uncertainty that turbulences might dampen the statistical significance of the January effect. By contrast, when the market is calm, statistical evidence in favor of the January effect arises more easily.

It can be also notice in Table 2 that parameters $\theta_{i}^{h}$ and $\theta_{i}^{l}$ are in most cases larger than the parameters in vectors $\phi_{i}^{h}$ and $\phi_{i}^{l}$, which means that the individual indirect effects through the $F F F$ seem to have a low weight in the total effect. Moreover, according to the parameters significant at the $5 \%$ level in Table 2, most of the individual indirect effects come from factors $E R M$ and $S M B$.

Figure 1 shows the total January effect $\left(\lambda_{i t}\right)$ over time. In general, the effect seems fairly stable with some peaks on certain dates for some portfolios. It can be also seen that it is negatively correlated with size, as previous evidence in literature has suggested. However, in Figure 1 it is striking that the January effect may be negative in some periods, e.g. portfolio 4 . Typically, the relevant literature finds a positive January effect.

Tabla 3 shows the average of the total January effect $\left(\lambda_{i t}\right)$ throughout the sample period and its decomposition across volatility regimes $\left(\delta_{i t}^{h}, \delta_{i t}^{l}\right)$. For the total January effect, as mentioned above, there is negatively correlation with size. However, an inspection of the January effect across volatility regimes shows that the negative correlation with size is not so clear. In the high regime, Portfolios 1 and 2 are again the most affected, but the positions for portfolio 3 to 5 are very different. In the low volatility regime, the most affected is portfolio 3 , followed by 1 and 4 . Therefore, the previous evidence that relates the magnitude of the January effect with the size of portfolios is only fulfilled when a total effect is considered: once we disentangle the effect across volatility regimes that correlation fails.

Although a quick inspection of the Figure 1 suggests a stable January effect as mentioned above, we evaluate whether it is suffering a decline, as has been argued in relatively recent literature. The key year we take into account is 1983. Since the publication of the articles of Keim (1983), Reinganum (1983) and Roll (1983) the January effect seems to have become popular, and they were in any event the first to relate the January effect with the size of firms. Therefore, we split the total sample period into two, 1940-1983 and 1984-2006, and calculate the average of January effect for the five size portfolios across the sub-sample periods. If financial markets are 
efficient, after the publication of those articles the January effect should be at least expected to diminish for 1984-2006. Table 4 shows that the average of the total January effect diminishes in the second period for all size portfolios except portfolio 1, for which it is even larger. Notice that portfolios 2 and 3 feature a slight decrease in the January effect while for portfolio 4 and 5 the decrease is a little larger. The results, in general, support a decline in the January effect, albeit one that is not so noticeable as claimed by Yanxiang $\mathrm{Gu}$ (2003) and Marquering et al. (2006).

\section{Conclusions}

In this article we present evidence on the January effect on stock returns across volatility regimes. We use a Markov switching model, which allows us to distinguish two volatility regimes (high and low). We have obtained a time-varying January effect that is, in general, positive and significant in both volatility regimes. Although, the number of significant coefficients is larger in the low volatility regime, the magnitude of January effect is substantially larger in the high volatility regime.

Estimations for the Fama-French factors show that the factor that reflects the book-to-market effect $(H M L)$ suffers the largest January effect, which could be related to the fact that investors may recompose portfolios in favor of undervalued stocks in January.

Our specification for size portfolios indicates that Fama-French factors indirectly convey one joint effect plus other individual effects related to each factor. Estimations reveal that the January effect is significant for all size portfolios by contrast with most previous evidence that relates the January effect with small size portfolios.

We have also found, as in previous literature, that the total January effect is negatively correlated with the size of portfolios. However, across the volatility regimes that correlation fails.

The time-varying specification of the January effect enables evidence on whether it is suffering a decline. The results support a decline in the January effect for all size portfolios except the smallest portfolio, for which it is even larger. 


\section{References}

[1] Al-Khazali, O. M. 2001. Does the January Effect exist in High-Yield Bond Market?. Review of Financial Economics, 10, 71-80.

[2] Asteriou, D. and Kavetsos, G. 2006. Testing for the existence of the 'January Effect' in transition economies. Applied Financial Economics Letters, 2, 375-381.

[3] Bergs, A., McConnell, J. J. and Schalarbauhm, G.G. (1984). The Turnof-the-year-effect in Canada. The Journal of Finance, 39(1), 185-192.

[4] Chen, H. and Singal, V. 2004. All Things Considered, Taxes Drive the January Effect. The Journal of Financial Research, 27, 3, 351-372.

[5] Chia-Shang, J.C., Liu, T. and Rathinasamy, R.S. 2004. Robust Test of the January Effect in Stock Markets Using Markov-Switching Model. Journal of Financial Management and Analysis 17, 1, 22-33.

[6] Chien, C., C. Lee and A.M.L. Wang. 2002. A Note on Stock Market Seasonality: The impact of stock price volatility on the application of dummy variable regression model. The Quarterly Review of Economics and Finance, 42, 155-162.

[7] Choudhry, T. 2001. Month of the Year Effect and January Effect in pre-WWI Stock Returns: Evidence from a Non-Linear GARCH Model. International Journal of Finance and Economics, 6, 1, 1-11.

[8] Cooper, M. J., McConnell, J. J., and Ovchinnikov, A. V. 2006. The other January Effect. Journal of Financial Economics, 82, 315-341.

[9] Fama, E. F. and F. R. French. 1993. Common Risk Factors in the Returns on Stocks and Bonds. Journal of Financial Economics 33, 3-56.

[10] Fama, E. F. and F. R. French. 1996. Multifactor Explanations of Asset Pricing Anomalies. The Journal of Finance 51(1), 55-84.

[11] Galariotis, E. C. 2004. Sources of Contrarian Profits and Return Predictability in Emerging Markets. Applied Financial Economics, 14, 1027-1034. 
[12] Hamilton, J., 1989. A new Approach of the Economic Analysis of Nonstationary Time Series and the Business Cycle. Econometrica 57, 357-384.

[13] Hillier, D. and Marshall, A. 2002. Insider Trading, Tax-Loss Selling, and the Turn-of-the-year Effect. International Review of Financial Analysis, $11,73-84$.

[14] Keim, D.B. 1983. Size-Related Anomalies and Stock Return SeasonalityFurther Empirical Evidence. Journal of Financial Economics, 12, 13-32.

[15] Kim, D. 2006. On the Information Uncertainty Risk and the January Effect. Journal of Business, 79, 4, 2127-2162.

[16] Lean, H. H., Smyth, R. and Wong, W. 2007. Revisiting Calendar Anomalies in Asian Stock Markets using a Stochastic Dominance Approach. Journal of Multinational Financial Management, 17, 125141.

[17] Marquering, W., Nisser, J. and Valla, Toni. 2006. Disappearing Anomalies: a Dynamic Analysis of the Persistence of Anomalies. Applied Financial Economics, 16, 291-302.

[18] Reinganum, M. R. 1983. The Anomalous Stock Market Behavior of Small Firms in January - Empirical Test for Tax-Loss Selling Effects. Journal of Financial Economics, 12, 89-104.

[19] Rendon, J. and Ziemba, W.T. 2007. Is the January effect still alive in the futures markets?. Financial Markets and Portfolio Management, 21 (3), 381-396.

[20] Roll, R. 1983. Vas ist das?. The Turn-of-the-Year Effect and the Return Premia of Small Firms. Journal of Portfolio Management, 9, 18-28.

[21] Rozeff, M. S. and Kinney, W. R. 1976. Capital Market Seasonality: The Case of Stock Returns. Journal of Financial Economics, 3, 379-402.

[22] Silvapulle, P. 2004. Testing for Seasonal Behavior of Monthly Stock Returns: Evidence from International Markets. Quarterly Journal of Business and Economics, 42, 1/2, 93-109. 
[23] Starks, L.T., Yong, L. and Zheng, L. 2006. Tax-Loss Selling and the January Effect: Evidence from Municipal Bond Closed-End Funds. The Journal of Finance, 61, 6, 3049-3067.

[24] Tonchev, D. and Kim, T. 2004. Calendar Effects in Eastern European Financial Markets: Evidence from the Czech Republic, Slovakia and Slovenia. Applied Financial Economics, 14, 1035-1043.

[25] Yanxiang Gu, A. 2003. The Declining January Effect: Evidence from the U.S. Equity Markets. The Quarterly Review of Economics and Finance, 43, 4, 395-404.

[26] Zhang, B. and Li, X. 2006. Do Calendar Effects Still Exist in the Chinese Stock Markets?. Journal of Chinese Economic and Business Studies, 4, $2,151-163$. 
Table 1: Estimation for the Fama-French three factors

\begin{tabular}{llll}
\hline \hline & $E R M$ & $S M B$ & $H M L$ \\
\hline High Volatility & & & \\
\hline January Dummy & 0.0194 & 0.0320 & $0.0313^{*}$ \\
& $(0.0141)$ & $(0.0166)$ & $(0.0093)$ \\
Low Volatility & & & \\
\hline January Dummy & $0.0111^{*}$ & $0.0155^{*}$ & $0.0183^{*}$ \\
& $(0.0051)$ & $(0.0043)$ & $(0.0028)$ \\
& & & \\
\hline Standard errors in parentheses & & \\
* Significant at 5\% level & & \\
\hline \hline
\end{tabular}

Table 2: Estimation for the returns on size portfolios

\begin{tabular}{|c|c|c|c|c|c|}
\hline & $q_{1}$ & $q_{2}$ & $q_{3}$ & $q_{4}$ & $q_{5}$ \\
\hline \multicolumn{6}{|c|}{ High volatility } \\
\hline$\theta^{h}$ & $\begin{array}{l}0.0483^{*} \\
(0.0012)\end{array}$ & $\begin{array}{l}0.0352^{*} \\
(0.0014)\end{array}$ & $\begin{array}{l}0.0175 \\
(0.0119)\end{array}$ & $\begin{array}{l}0.0330 \\
(0.0578)\end{array}$ & $\begin{array}{l}0.0066^{*} \\
(0.0004)\end{array}$ \\
\hline$\phi_{E R M}^{h}$ & $\begin{array}{l}0.0116^{*} \\
(0.0032)\end{array}$ & $\begin{array}{l}-0.0046 \\
(0.0069)\end{array}$ & $\begin{array}{c}-0.0173 \\
(0.0356)\end{array}$ & $\begin{array}{l}0.0358 \\
(0.0214)\end{array}$ & $\begin{array}{l}0.0102^{*} \\
(0.0011)\end{array}$ \\
\hline$\phi_{S M B}^{h}$ & $\begin{array}{l}0.0148^{*} \\
(0.0024)\end{array}$ & $\begin{array}{l}0.0095 \\
(0.0086)\end{array}$ & $\begin{array}{l}-0.0166 \\
(0.0155)\end{array}$ & $\begin{array}{l}0.0323 \\
(0.0494)\end{array}$ & $\begin{array}{l}0.0004 \\
(0.0012)\end{array}$ \\
\hline$\phi_{H M L}^{h}$ & $\begin{array}{l}-0.0059^{*} \\
(0.0027)\end{array}$ & $\begin{array}{l}-0.0021 \\
(0.0054)\end{array}$ & $\begin{array}{l}0.0413 \\
(0.0315)\end{array}$ & $\begin{array}{l}-0.0837^{*} \\
(0.0361)\end{array}$ & $\begin{array}{l}0.0011 \\
(0.0012)\end{array}$ \\
\hline \multicolumn{6}{|c|}{ Low Volatility } \\
\hline$\theta^{l}$ & $\begin{array}{l}-0.0120 \\
(0.0219)\end{array}$ & $\begin{array}{l}0.0230^{*} \\
(0.0015)\end{array}$ & $\begin{array}{l}0.0248^{*} \\
(0.0019)\end{array}$ & $\begin{array}{l}0.0204^{*} \\
(0.0008)\end{array}$ & $\begin{array}{l}0.0029^{*} \\
(0.0011)\end{array}$ \\
\hline$\phi_{E R M}^{l}$ & $\begin{array}{l}0.0039 \\
(0.0163)\end{array}$ & $\begin{array}{l}0.0110^{*} \\
(0.0030)\end{array}$ & $\begin{array}{l}0.0125^{*} \\
(0.0027)\end{array}$ & $\begin{array}{l}0.0110^{*} \\
(0.0029)\end{array}$ & $\begin{array}{l}0.0042^{*} \\
(0.0019)\end{array}$ \\
\hline$\phi_{S M B}^{l}$ & $\begin{array}{l}0.0558^{*} \\
(0.0195)\end{array}$ & $\begin{array}{l}0.0097^{*} \\
(0.0024)\end{array}$ & $\begin{array}{l}-0.0071^{*} \\
(0.0016)\end{array}$ & $\begin{array}{l}-0.0117^{*} \\
(0.0014)\end{array}$ & $\begin{array}{l}0.0047^{*} \\
(0.0021)\end{array}$ \\
\hline$\phi_{H M L}^{l}$ & $\begin{array}{l}0.0847^{*} \\
(0.0148) \\
\end{array}$ & $\begin{array}{l}0.0032 \\
(0.0022) \\
\end{array}$ & $\begin{array}{l}-0.0014 \\
(0.0023) \\
\end{array}$ & $\begin{array}{l}-0.0010 \\
(0.0012) \\
\end{array}$ & $\begin{array}{l}0.0024 \\
(0.0025) \\
\end{array}$ \\
\hline * Sig & $\begin{array}{l}\text { in parent } \\
5 \% \text { level }\end{array}$ & & & & \\
\hline
\end{tabular}


Table 3: Average of the January effect 1940-2006

\begin{tabular}{ccclll}
\hline \hline & $q_{1}$ & $q_{2}$ & $q_{3}$ & $q_{4}$ & $q_{5}$ \\
\hline $\bar{\lambda}_{i}$ & 0.0624 & 0.0335 & 0.0237 & 0.0091 & 0.0083 \\
$\bar{\delta}_{i}^{h}$ & 0.0442 & 0.0185 & 0.0000 & -0.0078 & 0.0046 \\
$\bar{\delta}_{i}^{l}$ & 0.0182 & 0.0150 & 0.0237 & 0.0169 & 0.0037 \\
\hline \hline
\end{tabular}

Table 4: Average of the Total January effect across sub-sample periods

\begin{tabular}{llllll}
\hline \hline & $q_{1}$ & $q_{2}$ & $q_{3}$ & $q_{4}$ & $q_{5}$ \\
\hline & & & & & \\
$1940-1983$ & 0.0610 & 0.0343 & 0.0244 & 0.0124 & 0.0089 \\
$1984-2006$ & 0.0649 & 0.0319 & 0.0224 & 0.0028 & 0.0077
\end{tabular}




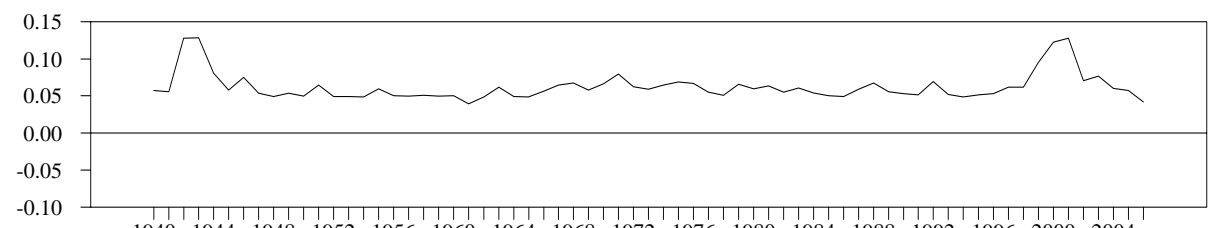

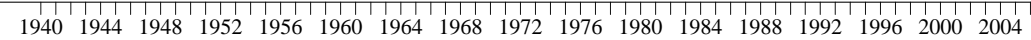

size 1

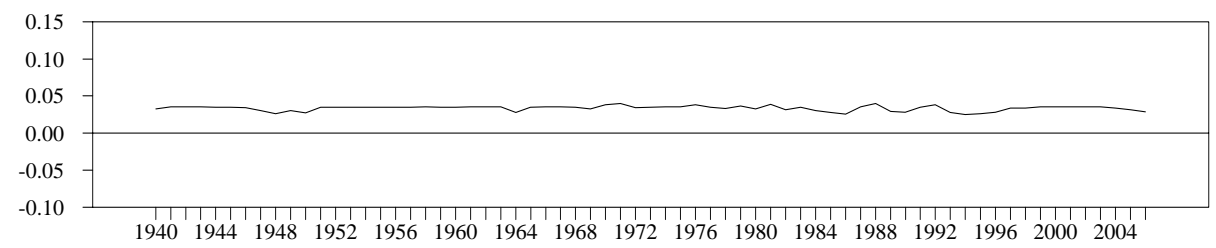

size 2

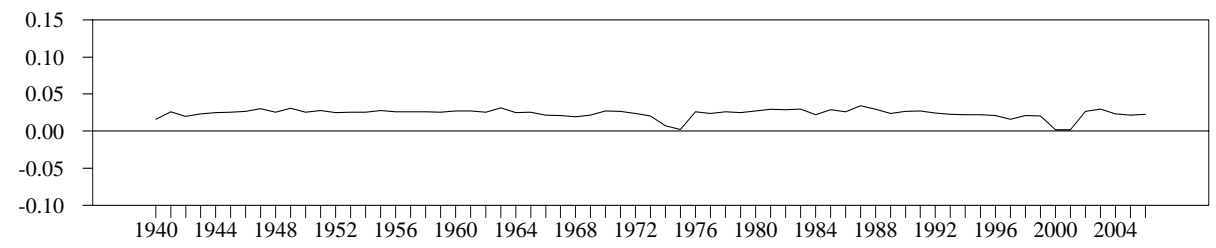

size 3

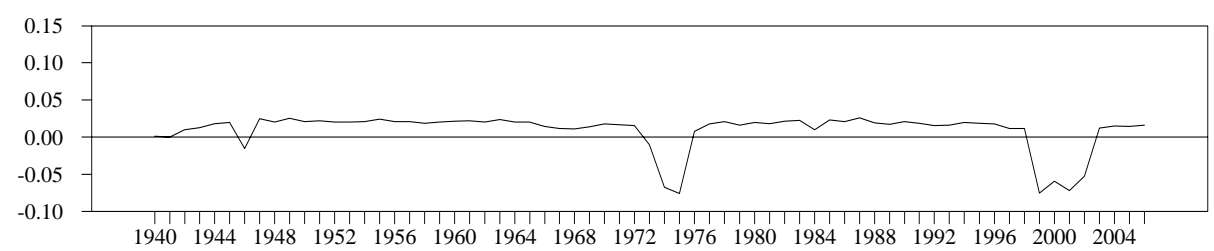

size 4

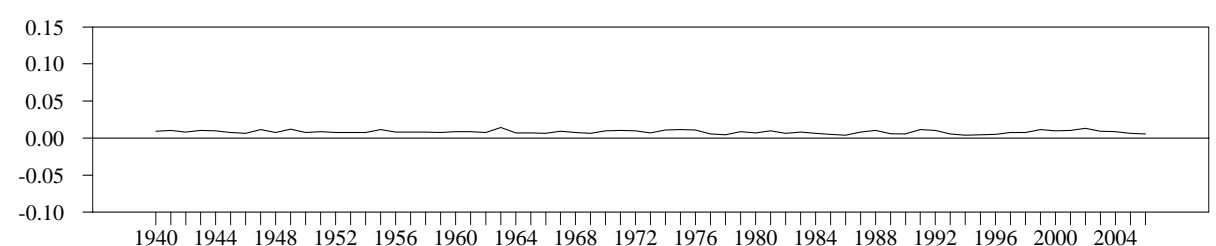

size 5

Figure 1: Total Time-Varying January effect for size portfolios. 